\title{
The Impact of Functional Strength Training on Some Physical Variables and the Level of Some Offensive Strikes in Tennis Players
}

\section{"Dr/ Sahar Hassan Mohamed}

Introduction and research problem

The sport of tennis is one of the individual games that have been positively affected by the development of science related to the field of sports and the development of methods and ways of player's preparation,

Which contributed to the upgrading of players physically and technically, which helped them to achieve the achievement of excellence and athletic achievement?

The game of tennis is characterized by a variety of basic and complex skill, which requires not only training in the performance of skill only, where the nature of skills in the game of tennis, a variety of abilities and a comprehensive and to achieve a high level of performance in this sport. (54:17)

Al Owais Al-Jabali (2000) and Mohammed AlWalyali (2000) agree that the training process has taken great strides in progress in our modern era.

It has become suitable for the players and the coach is constantly following the training in order to be able to do the best and the greatest in this field. And raises the level and performance of his players. $(52: 14)(68: 16)$

That the training methods of the athlete are necessary to implement the training program to develop the training condition of the player by the behavior of the closest means to achieve the required, known as the well-planned system of positive interaction between the trainer and the player to follow the path to the goal of the training process. ( $1 \leqslant 1: 1 \%)$

Since proper planning to raise the efficiency of different sports players is important, such as planning how to learn basic skills and raise the level of physical and skill efficiency.

Access to high levels of sport is not a coincidence but a

"Lecturer at the Department of Sports Games, Faculty of Physical Education, Tanta University

Assiut Journal For Sport Science Arts 
long-term plan with limited goals. 2007), and Ahmed Amin Fawzi (2004) that skill refers to the ability of the individual to perceive the complex dynamics easily and accurately and quickly respond to changing situations to achieve the best results $(6: 177)(1: 30)$

The sport of tennis, although it is one of the individual games that require a lot of self-training of the basic skills and different play plans, But the level is not only through the constructive cooperation between researchers and trainers as the methods of numbers must be balanced and inclusive of all factors. (54: 9)

Zafer Ismail (2003) says that tennis is one of the most important sports games in the world. It is important for many people in the world because of its suitability for all ages and its suitability for each race according to its abilities. It requires only four or more players. It is a powerful activity that helps to increase physical fitness. (8:10) (10:20)

According to Kamal Abdul Hamid (2010), in order for the racquetball to maintain its position, the players had to perform all the basic skills at an adequate level of ability.

The more skillful players were, the greater the ability to perform the duty-line, defensive or offensive. Thus increasing the chances of winning the trophies (59:15)

Aline Wadie (2001) states that each game has its own public and private abilities that help improve the performance of its skill.

The level of fitness of each youngster varies according to his / her abilities and ability to be fit in the tennis game. He needs physical preparation in respiratory endurance and speed Consistency, muscular strength and flexibility at a balanced level (115: 5)

The ground strikes are the first skills learned by the beginner, such as learning once how to hold the racket and swing and the correct distance between the ball and the point of contact with the ball.

Here the novice learns to guide the ball in the direction required and control the ball and repeat so much so that this skill is familiar and automatic and should be given the coach is very important because it is these strikes that pave the way for all kinds of other strikes 
and thus improve tennis performance.

The strike is the only thing in tennis matches that gives you many advantages. It gives you the opportunity to set the game to score points, And the transmission gives you the psychological advantage of being in the position of the attacker, putting your opponents in the defense of the home, (6: 129) to earn points without effort to run to meet the ball and defend his home.

The transmission is one of the most important skills in tennis, which is characterized by beauty and motor flow to adopt the player in the performance of the performance of the technical excellence (characteristic technical performance), which reflects the dynamic composition of the skill, within the framework of the essential skills of tennis. (28: 32)

The development of functional power is one of the basic components that must be developed through formalized training programs.

It is a combination of strength training with balance exercises, and it is as important as muscle strength that combines strength training with speed.

In the view of the researcher that the functional force of the basic components to achieve the basic strikes, and faded imbalance that may result when hitting the ball with a bat strongly, And the player to bear in mind that he may be paid him strikes suddenly lose his balance while preparing to pay, so the strikes must be characterized Strength and balance, as well as strength and speed in both directions of the stadium.

This is confirmed by Vom Hofe (1995) that muscle strength and balance are the main elements of functional training.

The integration between muscular strength and motor speed results in muscular strength or velocity. The integration of muscular strength and balance produces an effective functional force (34: 249) )

Fabio Comana (2004) believes that balance in muscular work is a key element in functional strength training, not only the balance between strength and flexibility or active and non-functioning muscles, But also what we may 
think are methods used. For example, stand on one foot and be able to Move other body organs without falling, and this is an important interactive feature in functional strength exercises. (52:27)

And that all the forms of mobility originates in the center of the body and adds that the term (functional) seems to be a little unclear, functional functions are the movements of such movements that the body designed to perform in life, So the coaches athletes who use force training with their players need to know the geometry of the human body and how Works in normal life (31: 509)

Scott Gaines (2003) points out that all training programs must include functional strength training, and demonstrates that if we notice the players during their competitions,

There are very few periods in which the player is based on both feet and even more so that the sports practiced from the sitting position very few such as rowing and therefore the traditional exercises,

Which exercise most of the exercises of sitting or standing does not fit athletes in most sports activities individual and collective (32: 214).

In the course of the work of the researcher in the teaching of tennis in the second year students at the Faculty of Physical Education, Tanta University noted that the students lose to the kinetic equilibrium during the performance of the skills determined in the third division such as (front and back blows and transmission)

And the weakness of the force of the strike to the opposing field and through the researcher's view of the scientific study Amal Morsi (2005) (3) Entitled "The effectiveness of integrated functional force training on some special physical variables and the level of performance of some of the balances and (7) Entitled "Proposed training program for functional strength to improve some of the physical and skill variables of the football player, and the study of Rida Mohammed Ibrahim (2009) (8)

Entitled"

The effectiveness of strength training on the strength of muscles The Center and the 
driving forces and their relation to the level of skilled performance in the back crawling, and the study of Azza Khalil Mahmoud (2007) (12)

Entitled the effectiveness of functional strength training on the expression of the genome of superoxide oxide and some physical variables and the time of swimming $800 \mathrm{~m}$ free, And study of Nariman Hassani, Nada Hamed Ramah (2005) (21) entitled the effectiveness of training The strength of the functional complementarily on some physical variables and the level of performance on the device movements ground,

Which indicate all the results to the importance of the use of power training exercises to achieve the strength and balance of sports practitioners

The researcher considered the importance of conducting this study to identify the impact of strength training on some functional physical variables and some level of offensive strikes by tennis players.

\section{Search Goal:}

The aim of this research is to identify the effect of functional strength training on some physical variables and the level of some of the offensive strikes of tennis players

\section{Research hypotheses}

- There are statistically significant differences between the averages of pre and post measurements in the level of some physical variables and the level of basic skills in the tennis player's experimental group.

- There are statistically significant differences between the averages of pre and post measurements at the level of some physical variables and the level of basic skills of the tennis players control group.

- There are statistically significant differences between the averages of the two dimensions in the experimental and control groups at the level of some physical variables and basic skills of tennis players and for the experimental group.

\section{Research plan and procedures}

\section{Research Methodology}

The researcher used the experimental method using the pre and post measurements of two groups, one experimental and the other control, to suit the nature of the research.

\section{Society and sample research}

The research society consisted of students of the second group at the Faculty of 
Physical Education, Tanta University, ranging in age from 18-20 years for the academic year 2015-2016.

The researcher chose the research sample by 56 students from the second division, divided into two groups (20) students, in addition to (16) students to carry out the exploratory experiment for research and from outside the

\section{Table (1)}

sample of the research has been selected for this sample for the following reasons:

1- The researcher shall teach this sample.

2 - Availability of the sample required for research procedures in terms of the number of female students. 3 Availability of the place and tools to conduct the research.

- Equal search sample

The significance of the differences between the control and experimental groups in the basic variables Physical and basic skills are under consideration $N=\mathbf{4 0}$

\begin{tabular}{l|c|l|l|l|l|l}
\hline \hline \multirow{2}{*}{ Variables } & \multirow{2}{*}{$\begin{array}{c}\text { Measurement } \\
\text { unit }\end{array}$} & \multicolumn{2}{|c|}{$\begin{array}{c}\text { Control } \\
\text { group }\end{array}$} & \multicolumn{2}{|c|}{$\begin{array}{c}\text { Experimental } \\
\text { group }\end{array}$} & $\begin{array}{c}\text { T } \\
\text { value }\end{array}$ \\
\cline { 3 - 7 } & $\mathrm{M}$ & $\mathrm{E}$ & $\mathrm{M}$ & $\mathrm{E}$ & \\
\hline \hline Age & Year & 16.3 & 0.69 & 16.4 & 1.01 & 0.63 \\
\hline Height & $\mathrm{Cm}$ & 168.8 & 2.10 & 169.9 & 3.80 & 0.69 \\
\hline Wight & $\mathrm{kg}$ & 70.5 & 10.3 & 70.7 & 10.8 & 0.25 \\
\hline $\begin{array}{l}\text { The training } \\
\text { age }\end{array}$ & Year & 4.65 & 0.38 & 4.17 & 0.24 & 0.62 \\
\hline $\begin{array}{l}\text { The strength } \\
\text { of the right } \\
\text { fist }\end{array}$ & $\mathrm{Kg}$ & 24.5 & 0.46 & 24.38 & 0.45 & 0.31 \\
\hline $\begin{array}{l}\text { The strength } \\
\text { of the left fist }\end{array}$ & $\mathrm{Kg}$ & 20.75 & 1.03 & 20.5 & 0.92 & 0.32 \\
\hline $\begin{array}{l}\text { Strength of } \\
\text { the muscles of } \\
\text { the feet }\end{array}$ & $\mathrm{Kg}$ & 38.51 & 0.52 & 38.68 & 0.22 & 0.36 \\
\hline \hline
\end{tabular}

Follow Table (1)

The significance of the differences between the control and experimental groups in the basic variables Physical and

Assiut Journal For Sport Science Arts 
basic skills are under consideration $N=\mathbf{4 0}$

\begin{tabular}{|c|c|c|c|c|c|c|}
\hline \multirow[t]{2}{*}{ Variables } & \multirow{2}{*}{$\begin{array}{c}\text { Measurement } \\
\text { unit }\end{array}$} & \multicolumn{2}{|c|}{$\begin{array}{c}\text { Control } \\
\text { group }\end{array}$} & \multicolumn{2}{|c|}{$\begin{array}{l}\text { Experimental } \\
\text { group }\end{array}$} & \multirow{2}{*}{$\begin{array}{c}\mathbf{T} \\
\text { value }\end{array}$} \\
\hline & & M & E & M & E & \\
\hline $\begin{array}{l}\text { Strength of } \\
\text { arm muscles }\end{array}$ & $\mathrm{Kg}$ & 31.25 & 0.36 & 31.55 & 0.15 & 0.52 \\
\hline Stand on one foot & $\mathrm{S}$ & 11.15 & 0.51 & 11.21 & 0.28 & 0.69 \\
\hline $\begin{array}{l}\text { Stand on the } \\
\text { level of elevation }\end{array}$ & $\mathrm{S}$ & 3.15 & 1.15 & 3.20 & 1.15 & 0.65 \\
\hline $\begin{array}{l}\text { The accuracy } \\
\text { of the ground } \\
\text { front impact }\end{array}$ & Degree & 4.85 & 0.65 & 4.81 & 0.65 & 0.457 \\
\hline $\begin{array}{l}\text { The accuracy } \\
\text { of the rear } \\
\text { strike Floor }\end{array}$ & Degree & 4.51 & 0.24 & 4.31 & 0.24 & 0.32 \\
\hline $\begin{array}{lr}\text { First shoot } \\
\text { accuracy }\end{array}$ & Degree & 3.72 & 0.47 & 3.74 & 0.32 & 0.85 \\
\hline
\end{tabular}

The value of "T" is the table at $(0.05)=1.684$

It is clear from the previous table (1) that there are no statistically significant differences between the control and experimental groups in the variables under study, indicating the equivalence of the two groups in the physical variables and the level of physical abilities and basic skills.

Search tools:

The researcher used several tools to achieve the research objectives, including data collection tools

First: a form for recording data
- List of experts' names. Annex (1)

- Expert feedback questionnaire on the content of the proposed program. Annex (3)

- Form of registration of personal data for each student (name - age - height - weight) and physical and skill variables. Annex (6)

Second: Instruments and measuring instruments used:

1- Measurement of length in centimeters by the device of the Rustameter.

2- The digital stopwatch of one type works for the nearest $1 / 100$ of the $w$. 
3- A device to measure the fixed strength of the muscles of the two feet

4- Dynamometer measures the strength of the grip.

5- Iron bar multi-weights to measure the strength of the muscles of the arms.

6. Vertical Jump Scale

7- Electronic balance of weight (kg)

Third: Tests used in research: -

Physical tests:

The researcher selected the physical tests based on the questionnaire which was presented to the experts to choose the most appropriate physical tests for this stage.

Physical tests: Attachment (2)

- Fixed strength test of the muscles for both feet.

- Stand on one foot as long as possible

- Stand on a $30 \mathrm{ft}$ upgrade foot.

- Test dynamometer to measure the strength of the right and left fist.

- Test the lifting of the weight of an iron bar to measure the strength of the muscles of the arms.

2- Technical tests: Attachment
7- Front ground strike: the test (White) to measure the accuracy of the front impact.

8. Rear ground strike: White test to measure the accuracy of the rear strike.

9- Transmission Blow: A test to measure the precision of the transmission blow.

Assess the skill level of basic tennis skills:

It is an important method of observation based on the evaluation of the technical performance of the skill, and that the accuracy of this skill depends on the experience of the scientific evaluator and the extent of his knowledge of the way the performance of the technical skill of that skill,

So the researcher used this method to assess the level the technical performance in acquiring the skills under consideration by dividing each skill of tennis into three parts (the preparatory, main and final parts).

After developing the special specifications and the explanatory picture for each part of the skill, (10) degrees, and the most frequently taken for each part, according to the opinions of specialists agreement class according to 
the importance of each part of the skill and the points given to them parts, and Table 3 shows the distribution of grades by parts of each skill and relying on the opinions of specialists

Table (2)

Shows the distribution of grades to assess the performance art of the basic skills in question

\begin{tabular}{l|c|c|c|c}
\hline \hline Strikes & $\begin{array}{c}\text { Preparatory } \\
\text { part }\end{array}$ & $\begin{array}{c}\text { The main } \\
\text { part }\end{array}$ & $\begin{array}{c}\text { Final } \\
\text { part }\end{array}$ & $\begin{array}{c}\text { Full } \\
\text { mark }\end{array}$ \\
\hline \hline Front ground strike & 3 & 5 & 2 & 10 \\
\hline Rear ground strike & 3 & 5 & 2 & 10 \\
\hline Serf strike & 4 & 4 & 2 & 10 \\
\hline \hline
\end{tabular}

The content of the proposed program for training the functional force:

Some of the Arab and foreign references were used, such as the study of Mahmoud Ahmad, Muhammad Ahmad (2004), 18 Mahmoud Metwally (2006), 19 Walid Saleh (2014), 22 Mohamed Ibrahim (2010), 30 Christine (2000) 24), Cress ME (2000) (25) in the development of functional strength training to suit the objective of the research.

The functional strength training was applied to the experimental group only and ranged about 75 minutes (physical) Training of the two groups and the training of the functional force commensurate with the objective of the research and the duration of the program (8) weeks (2) weekly units.
Timetable of the contents of the training program of the two groups:

- Number of training units during the program implementation period (2 months) $=8$ weeks.

- Number of training units per week $=(2)$ units per week.

- The daily training time of the control and experimental groups (90) minutes.

Application of functional strength training:

The proposed strength training was applied to the experimental group for 8 weeks (2) units per week with (16) training units in the period from Sunday $28 / 2 / 2015$ to 26/4/2015.

A module for a training module

\begin{tabular}{l|l|l|l}
\hline \hline Type & Time & Target & \\
\hline \hline
\end{tabular}




\begin{tabular}{|c|c|c|c|}
\hline 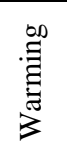 & $1 \cdot$ minutes & $\begin{array}{l}\text { Preparation } \\
\text { formation of muscles } \\
\text { and joints }\end{array}$ & $\begin{array}{l}\text { Running around the stadium and } \\
\text { then working group muscle } \\
\text { stretches }\end{array}$ \\
\hline 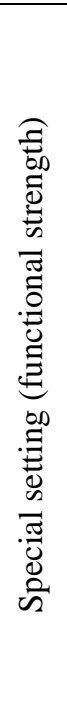 & $\begin{array}{l}\text { 纟o } \\
\text { minutes }\end{array}$ & (Power + balance $)$ & $\begin{array}{l}\text { From the position of the fetus is } \\
\text { jumping from the knees to reach the } \\
\text { position of bending the knees fully } \\
\text { and then jump to get to the position } \\
\text { on the knees- } \\
\text {-Using the small seats are running } \\
\text { quickly and then running on the } \\
\text { seats and roll and jump on the seat } \\
\text { and then open the feet and so on to } \\
\text { the end and then stand at the last } \\
\text { seat and bend the knees until sitting } \\
\text { on the seat and then stand and so on. } \\
\text {-From the position of the back on } \\
\text { the back with the bending of one of } \\
\text { the two feet are based on the foot } \\
\text { and buttocks and back and try to } \\
\text { bend the trunk a little forward with } \\
\text { the lifting of the man to the top. }\end{array}$ \\
\hline \multirow{2}{*}{ 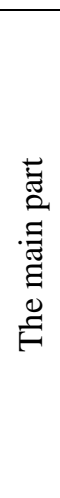 } & $\begin{array}{l}\text { ir } \\
\text { minutes }\end{array}$ & $\begin{array}{l}\text { Precision of Tennis } \\
\text { Balls trainings }\end{array}$ & $\begin{array}{l}\text { Each student will stand up to the student } \\
\text { and compete } \\
\text { A student throwing a handball to the } \\
\text { other player and holding the ball and } \\
\text { pass it back to the front } \\
\text {-Work the skill of transmission to the } \\
\text { number of (8) corrections of the pitch } \\
\text { width. (2) s for each performance }\end{array}$ \\
\hline & $\begin{array}{l}r \cdot \\
\text { minutes }\end{array}$ & $\begin{array}{l}\text { Skill } \\
\text { )Front and rear impact } \\
\text { power( }\end{array}$ & $\begin{array}{l}\text { Each student draws on specific } \\
\text { numbers on the pitch and then } \\
\text { running to be corrected on a smooth } \\
\text { wall numbered to accommodate the } \\
\text { forces of strikes in the students- }\end{array}$ \\
\hline $\begin{array}{l}\stackrel{\overparen{\Xi}}{\Xi} \\
\stackrel{\Xi}{E}\end{array}$ & rminutes & $\begin{array}{l}\text { Return to the state of } \\
\text { nature and relaxed body } \\
\text { after exercise }\end{array}$ & Small games + relaxation exercises \\
\hline
\end{tabular}

View and discuss the results:

First: View results:

Table (3) 
The significance of the differences between the pre measurement and the encroachment at some level Physical variables and skill level on the experimental search group $\mathrm{N}=20$

\begin{tabular}{|c|c|c|c|c|c|c|c|c|c|}
\hline \multirow{2}{*}{ Variables } & \multirow{2}{*}{$\begin{array}{c}\text { Measurement } \\
\text { unit }\end{array}$} & \multicolumn{2}{|c|}{$\begin{array}{c}\text { Pre } \\
\text { measurement }\end{array}$} & \multicolumn{2}{|c|}{$\begin{array}{c}\text { Post } \\
\text { measurement }\end{array}$} & \multirow{2}{*}{$\begin{array}{l}\text { Difference } \\
\text { between } \\
\text { the two } \\
\text { averages }\end{array}$} & \multirow{2}{*}{$\begin{array}{l}\text { Improvement } \\
\text { rate }\end{array}$} & \multirow{2}{*}{$\begin{array}{l}\text { Value } \\
\text { (T) }\end{array}$} & \multirow{2}{*}{$\begin{array}{c}\text { Level of } \\
\text { significance }\end{array}$} \\
\hline & & $\mathbf{S}$ & $\pm \mathbf{E}$ & $\mathbf{S}$ & $\pm \mathbf{E}$ & & & & \\
\hline $\begin{array}{l}\text { The } \\
\text { strength } \\
\text { of the } \\
\text { right fist }\end{array}$ & $\mathbf{K g}$ & 24.38 & 0.45 & 28.6 & 0.33 & 4.22 & $17.3 \%$ & 3.12 & Significance \\
\hline $\begin{array}{l}\text { The } \\
\text { strength } \\
\text { of the } \\
\text { left fist }\end{array}$ & $\mathbf{K g}$ & 20.5 & 0.92 & 24.5 & 0.68 & 4.00 & $19.5 \%$ & 3.25 & Significance \\
\hline $\begin{array}{l}\text { Strength } \\
\text { of the } \\
\text { muscles } \\
\text { of the } \\
\text { feet }\end{array}$ & $\mathbf{K g}$ & 38.68 & 0.22 & 44.08 & 0.59 & 5.40 & $5.52 \%$ & 2.87 & Significance \\
\hline $\begin{array}{c}\text { Strength } \\
\text { of arm } \\
\text { muscles }\end{array}$ & $\mathbf{K g}$ & 31.55 & 0.15 & 35.25 & 1.17 & 3.7 & $5.91 \%$ & 2.91 & Significance \\
\hline $\begin{array}{l}\text { Stand on } \\
\text { one foot }\end{array}$ & $\mathbf{S}$ & 11.21 & 0.28 & 16.91 & 1.28 & 5.7 & $11.8 \%$ & 3.01 & Significance \\
\hline $\begin{array}{c}\text { Stand on } \\
\text { the level } \\
\text { of } \\
\text { elevation }\end{array}$ & $\mathbf{S}$ & 3.20 & 1.15 & 4.15 & 1.35 & 0.95 & $29.6 \%$ & 5.17 & Significance \\
\hline $\begin{array}{l}\text { The } \\
\text { accuracy } \\
\text { of the } \\
\text { ground } \\
\text { front } \\
\text { impact }\end{array}$ & Degree & 4.85 & 0.65 & 6.89 & 0.51 & 2.04 & $61.2 \%$ & 7.33 & Significance \\
\hline $\begin{array}{l}\text { The } \\
\text { accuracy } \\
\text { of the } \\
\text { rear } \\
\text { strike } \\
\text { Floor }\end{array}$ & Degree & 4.51 & 0.24 & 6.54 & 0.15 & 2.3 & $59.2 \%$ & 7.99 & Significance \\
\hline $\begin{array}{c}\text { The } \\
\text { accuracy } \\
\text { of serf }\end{array}$ & Degree & 3.72 & 0.47 & 6.10 & 0.32 & 2.38 & $93.2 \%$ & 8.12 & Significance \\
\hline
\end{tabular}

The value of the "T" table (1.725) at the level of significance (0.05)

Table (3) shows that there are significant differences between the pre-measurement and the post-measurement in all the physical and skill tests under study.

The value of the calculated $\mathrm{T}$ is greater than the value of the t-table at the level 
of significance

Experimental research.

The value of the "T" table (1.725) at the level of significance $(0.05)$

Table (4) shows that there are significant differences between the pre-measurement and the post-measurement in all the physical and skill tests under study.

The value of (t) was greater than the value of $(t)$ in the table at (0.05) indicating the improvement of the physical and skill variables Control search.

\section{Table (5)}

Significance of differences between the two dimensions of the experimental group And control at the level of some physical variables And the level of basic skills $N=\mathbf{n}=2$

\begin{tabular}{l|c|c|c|c|c|c|l}
\hline \hline \multirow{2}{*}{ Variables } & \multirow{2}{*}{$\begin{array}{c}\text { Measurement } \\
\text { unit }\end{array}$} & \multicolumn{2}{|c|}{$\begin{array}{c}\text { Experimental } \\
\text { group }\end{array}$} & \multicolumn{2}{c|}{$\begin{array}{c}\text { Control } \\
\text { group }\end{array}$} & $\begin{array}{c}\text { T } \\
\text { value }\end{array}$ & $\begin{array}{c}\text { Level of } \\
\text { significance }\end{array}$ \\
\cline { 3 - 7 } & $\mathrm{S}$ & $\pm \mathrm{E}$ & $\mathrm{S}$ & $\pm \mathrm{E}$ & & \\
\hline \hline $\begin{array}{l}\text { The strength } \\
\text { of the right } \\
\text { fist }\end{array}$ & $\mathrm{Kg}$ & 28.6 & 0.33 & 26.2 & 0.68 & 2.66 & Significance \\
\hline $\begin{array}{l}\text { The } \\
\text { strength of } \\
\text { the left fist }\end{array}$ & $\mathrm{Kg}$ & 24.5 & 0.68 & 21.7 & 0.57 & 2.52 & Significance \\
\hline $\begin{array}{l}\text { Strength } \\
\text { of the } \\
\text { muscles of } \\
\text { the feet }\end{array}$ & $\mathrm{Kg}$ & 44.08 & 0.59 & 41.11 & 1.17 & 2.60 & Significance \\
\hline $\begin{array}{l}\text { Strength } \\
\text { of arm } \\
\text { muscles }\end{array}$ & $\mathrm{Kg}$ & 35.25 & 1.17 & 32.55 & 0.98 & 2.60 & Significance \\
\hline $\begin{array}{l}\text { Stand on one } \\
\text { fot }\end{array}$ & $\mathrm{S}$ & 16.91 & 1.28 & 12.05 & 0.66 & 2.60 & Significance \\
\hline $\begin{array}{l}\text { Stand on the } \\
\text { level of } \\
\text { elevation }\end{array}$ & $\mathrm{S}$ & 4.15 & 1.35 & 3.60 & 0.96 & 2.90 & Significance \\
\hline $\begin{array}{l}\text { The accuracy } \\
\text { of the ground } \\
\text { front impact }\end{array}$ & Degree & 6.89 & 0.51 & 5.10 & 0.54 & 3.20 & Significance \\
\hline $\begin{array}{l}\text { The accuracy } \\
\text { of the rear } \\
\text { strike Floor }\end{array}$ & Degree & 6.54 & 0.15 & 5.36 & 0.63 & 3.96 & Significance \\
\hline $\begin{array}{l}\text { First shoot } \\
\text { accuracy }\end{array}$ & Degree & 6.10 & 0.32 & 3.99 & 0.54 & 3.80 & Significance \\
\hline \hline
\end{tabular}

The value of the "T" table (1.684) at the level of significance (0.05) 
Table (5) shows that there are significant differences between the two dimensions in the experimental and control groups in all the physical and skill tests under study.

The calculated value $(\mathrm{t})$ was greater than the tabular value at the significance level (0.05) And skillful experimental group research.

\section{Discussion of results:}

It is clear from Table (3) that there are statistically significant differences between the tribal measurement and the post-measurement of the experimental group in the physical and skill tests of the second year students at the Faculty of Physical Education, Tanta University and for the post-measurement.

The researcher pointed out that the nature of the training of the proposed functional force, which is scientifically informed and directed directly to the training objective, led to improved performance of the motor skills (front-impactback-strike) in the experimental group.

This is confirmed by Aweys al-Jabali (2000 AD) that muscle strength is one of the most important physical elements needed by players since all movements depend on how to move the body, and muscles are the control of this movement by constriction and expansion from one position to another, The more effective these contractions are, and the more skillful the task is accomplished (14: 351-360).

The results of this study agree with Vom Hofe (2003) that functional strength training features focus on the center, where strong center muscles connect the lower end to the upper end, and that functional strength training involves multiple movements

The directions are multi-directional and perform exercises by focusing on one single limb, making it one of the best exercises used to improve the strength of the center muscles and the balance (34: 242)

This is confirmed by the Vasankari study (1996) 33 that the characteristics of functional strength training is the emphasis on the center that emphasizes the core, where the strong muscles of the center connect the lower end to the upper end, And the training of the functional force includes multi-directional movements to perform his exercises by 
focusing on one side single limb, making it one of the best exercises used to improve the strength of muscles center (mid body) and balance.

Thus, the first hypothesis, which states that there are statistically significant differences between the averages of tribal and remote measurements at the level of some physical variables and the level of basic skills of the tennis players in the experimental group, has been achieved.

Table (4) shows statistically significant differences between the pre-measurement and postmeasurement of the control group in the tests of the physical variables and the skill level of the basic skills of the students of the control group.

This is due to the impact of the training program for the group as a whole before separating the two groups and the various training courses that are directly related to the training objective of the program within the unit.

This is in line with what Essam after the Creator (2003), Osama Riyad (2003), has pointed out that training is a systematic physical process that is well planned and organized to develop the physical abilities of the individual and protect against exposure or repetition of injury during performance (10: 177). Thus, the second hypothesis, which states that there are statistically significant differences between the averages of tribal and remote measurements at the level of some physical variables and the level of basic skills of tennis players in the control group.

Table (5) shows statistically significant differences between the postmeasurement of the experimental group and the remote measurement of the control group in the physical tests and the skill level of the basic skills in tennis and for the post-measurement of the experimental group.

The researcher returns the result to using the proposed program using the strength training and the Exercises for the development of balance and muscle strength, which directly contributed to the improvement and development of the basic skills of tennis players.

In this regard, Vom Hofe (2001) points out that 
functional strength training is suitable for all individuals at different levels of training and aims to improve the relationship between muscles and the nervous system by converting the increase in strength gained from one movement to another movement Are considered necessary and important. (25:34)

Schmidt and Wulf (1997) assert that all kinetic forms originate from the center of the body.

The term "functional" appears to be a little unclear; functionalism is the movement of the movements that the body designed for its performance in life, So the athletes who use the training of the functional force with their players need to know the geometry of the human body and how it works in normal life (31: 509)

The link between strength and balance in the muscle is one of the main requirements in the performance of tennis players and the best ways to develop these two elements comes through exercises functional force,

Which leads to changes in the muscles of the nervous system, allowing for increased strength and balance, especially when performing the sudden movements

In response to the blows of the opponent and predict the direction of the tennis ball and that the increase in the speed of power means low performance time and this is what sports racquet needed.

That the diversity in the methods of sports training is important and required, taking into account in the preparation of training programs need to take into account the different forms of movements performed during the training period,

And the identification of the appropriate training and intensity and the optimal selection of speed of performance during training lead to improvement and development of physical performance and this Achieved by functional strength training. (20:23) (52:29)

The researcher may return this superiority as a result of the impact of training and functional strength of the training contained directly to the training target set for it.

Thus, the third hypothesis, which states that there are statistically 
significant differences between the averages of the two dimensions in the experimental and control groups at the level of some physical variables and basic skills of tennis players and for the experimental group, is achieved.

\section{Conclusions:}

- The use of functional strength training improves the level of some physical variables and basic skills of tennis players.

- The use of traditional exercises improves the level of some physical variables and basic skills of tennis players in a limited way.

- The use of functional strength training improves the performance of some basic skills in tennis (front-impact, rear-impact) and physical variables (muscle strength and balance) better than the traditional program applied to the control group.

\section{Recommendations:}

1- The application of strength training exercises the same intensity and frequency and the inter-comfort on the beginner of tennis for its role in improving the level of muscle strength and balance and the level of skill performance.

2- The need for the coaches of the youth in their training some of the training of the functional force.

3. Conduct similar studies in different stages of the age

\section{References}

$\begin{array}{llr}\text { 1- Abdel- } & \text { Nabi } & \text { El-Gamal } \\ \text { (1997): } & \text { The } & \text { Arabic }\end{array}$

Encyclopedia of Tennis 3, 1, Cairo.

2-Ahmed Amin Fawzi (2004): Basketball for Youngsters, Egyptian Library Alexandria.

\section{3-Ahmed Helal: Games} tennis (2013): Tennis, Faculty of Physical Education for Girls, Helwan University.

\section{4-Alain Wadih Faraj (2000} AD): Tennis EducationTraining- Evaluation- Greetings, Knowledge Foundation, Cairo.

\section{5-Alain Wadih Faraj (2007):}

The new in tennis, the way to the tournament, knowledge facility, Cairo.

\section{6-Amal Mohamed Morsy} (2005): The effectiveness of integrated functional force training on some special physical variables and the level of the performance of some of the balances and dynamics in rhythmic exercises, published research, Journal of Physical Education for Girls, Volume III, second half, Zagazig University.

7- Ashton ,T. ,Rowland ,C. ,Jones ,E. , Young ,I. Jackson 
,S. ,Davies ,B. and Peter, J.R. (1998): Selection spine resonance spectroscopic detection of oxygen ,centered radicals in human serum following exhaustive exercise ,Euro. Jou. Of applied physiol. and occupational pysiol., berline. 28 (771).

8-Azza Khalil Mahmoud (2007): the effectiveness of functional strength training on the expression of the genome of superoxide oxide and some physical variables and the time of swimming $800 \mathrm{~m}$ free, the Arab Conference, Cairo.

9- Christine Cunningham (2000): The Importance of Functional Strength Training, Personal Fitness Professional magazine, American Council on Exercise publication, April 10- Cress ME, Conley KE, Balding SL, Hansen-Smith F, Konczak J (2000): Functional training: muscle structure, function, and performance in older women, J Orthop Sports Phys Ther. Jul; 24(1):pp4-10

\section{1- Cymara P.K; David E.K;} Chris A.M and Donna M.S (2004): Chair rise and lifting characteristics of elders with knee arthritis :functional training and strengthening effects, J American Physical
Therapy Association Vol. 83 • N. 1 • January

\section{2- Dhafer Hashim Ismail:} (2003 AD) Technical and planning numbers Baltnsp, I 2, Dar Al-Hafiz for printing and evil and translation Baghdad.

\section{3-Essam Abdel Khalek} (2003): Mathematical training theories and applications, Dar Al Ma'arif, Cairo.

14- Fabio comana (2004): function training for sports, Human Kinetics: Champaign IL , England

15- Jim Courier: Tennis Tactics- Winning PatternsUSTA- Human Kinetics, 1996.

\section{6- Kamal Abdul- Hamad} Ismail (2010): Theories of games: hockey, small table tennis, tennis, badminton, book center for publishing, Alexandria.

17- Miyazaki H, Oh-ishi S, Ookawara T, Kizaki T, Nakao C, Sato Y, Haga S, and Ohno H. (2000) The effects of resistance training and functional exercises on the efficiency of life and reduce depression in the elderly. Adv Exerc Sports Physiol 6: 85-89

18- Mohamed Ibrahim Mahmoud Sultan The Influence of Using Functional Power Exercises on the Developing of Performance 
Level for Shooting Skill by the Front of the Foot for the Beginners Players in Soccer World Journal of Sport Sciences 3.2010

\section{9-Mahmoud} Mohamed Ahmed, Mohamed Mohamed Ahmed (2004): "The effectiveness of integrated functional exercises on some physical variables and the level of major elements in the blood and the level of digital achievement in the enemy of short distances," scientific production.

20-Mohamed Mohamed ElShahat (2003): Individual Games Guide: Tennis - Tennis, Karokiya, Judo, Badminton, Boxing, Fencing, Al-Eman Bookshop, Cairo.16-Mohamed Tawfiq Al-Walyli (2000): Training competitions, G.M.S, Cairo.

\section{1- Mahmoud Mohamed}

\section{Metwally}

(2006):

Effectiveness of the training of the functional force on some physical and skill variables and the level of the major elements in the blood of the football buds, Egyptian Journal of Basic and Applied Physiology, Volume 5, No. 2.

\section{2-Mona Gouda (2013):}

Tennis Games: tennis tennis wooden - tennis Faculty of
Physical Education for Girls, Helwan University.

\section{3- Nariman Al-Hassani,} Nada Hamed Rammah (2005): Effectiveness of integrated functional force training on some physical variables and level of performance on the ground movement apparatus, published scientific research, Faculty of Physical Education Girls, Journal of Comprehensive Education Research, Volume III, second half.

24- Osama Riyad (2003): Sports Medicine and Ground Tennis, National Guard Press, Saudi Arabia.31 - Schmidt, R. A. and G. Wulf .(1997): Continuous concurrent feedback degrades skill learning: implications for training and simulation. Human Factors 39: pp509-525 25- Owais Al-Jabali (2000): Mathematical Training (theory and practice), G.M.S Cairo.

\section{6-Rami Salama Mahmoud} (2011): "A proposed training program for the functional strength to improve some physical and skill variables for the originator of football", Master Thesis, unpublished, Faculty of Physical Education for Boys, Helwan University. 
27- Reza Mohammed Ibrahim (2009): "The effectiveness of strength training on the strength of the muscles of the center and the dynamics and their relationship to the level of performance skilled in the crawl on the back," MA, unpublished, Faculty of Physical Education for Girls, University of Zagazig.

28- Scott Gaines (2003):

Benefits and Limitations of Functional Exercise, Vertex Fitness, NESTA , USA

29- Tarek Hamoudi Amin (2002): Games of ball and rack, Dar books for printing and publishing, 4, University of Mosul.

30- Walid Saleh Abdul Jawad Eid: (2014) Effect of strength training on the level of performance of some skills of strength and stability on the throat for gymnasts under 10 years, Master, Faculty of Physical Education, Assiut University.

31- Vasankari M, Akyüz F, Turgut A, Getsfrid WM. (1996): Effect of aerobic and anaerobic metabolism on free radical generation swimmers. Med Sci Sports Exerc 2001;33:564-7
32- Vom Hofe, A.(1995): The problem of skill specificity in complex athletic tasks: a revisitation. International Journal of Sport Psychology 26, pp249-261.

\section{3- Yasumura S, Takahashi}

T, Hamamura A, Ishikawa

M, Ito H, Ueda Y, Takehara M, Miyaoka H, Murai C, Murakami S, Moriyama M, Yamamoto K, Yoshinaga T, Takeuchi T. (2000):

Characteristics of functional training and effects on physical activities of daily living, Nippon Koshu Eisei Zasshi. Sep; 47 (9): pp792-800. 